\title{
Anti-wrinkle Activities Verification of Buplerum falcatum Extracts on CCD-986sk
}

\author{
Dong-Hee Kim • Tae-Soon Park • Jun-Ho Son*
}

CCD-986sk세포내 시호 추출물의 항주름 활성 검증

\author{
김동희 · 박태순 · 손준호*
}

Received: 15 January 2015 / Accepted: 26 March 2015 / Published Online: 30 June 2015

(C) The Korean Society for Applied Biological Chemistry 2015

\begin{abstract}
The electron donating ability, elastase inhibitory, procollagen synthesis and Matrix metalloprotease-1 (MMP-1) activities were measured in order to verify the anti-wrinkle properties of extracts from Buplerum falcatum as a functional ingredient for cosmetic products. Electron donating ability and elastase inhibition activities were 80 and $52 \%$ at a dose of $1,000 \mu \mathrm{g} / \mathrm{mL}$ of B. falcatum $70 \%$ ethanol extract. Pro-collagen synthesis was increased with the increase concentration of $B$. falcatum extract on CCD-986sk in addition to decrease the amount of protein of MMP-1. The results suggested that $B$. falcatum extract can be used to reduced electron donating ability, elastase, pro-collagen synthesis and MMP-1 activity and is a potential candidate for cosmedical materials.
\end{abstract}

Keywords Buplerum falcatum $\cdot$ elastase $\cdot$ Matrix metalloprotease$1 \cdot$ pro-collagen

\section{서 론}

최근 약용식물의 재배는 높은 소득과 수출에 크게 기여할 작물

D.-H. Kim · T.-S. Park · J.-H. Son

Korea Promotion Institute for Traditional Medicine Industry, Gyeongbuk $712-260$, Republic of Korea

*Corresponding author (J.-H. Son: bio115@kotmin.kr)

This is an Open Access article distributed under the terms of the Creative Commons Attribution Non-Commercial License (http://creativecommons. org/licenses/by-nc/3.0/) which permits unrestricted non-commercial use, distribution, and reproduction in any medium, provided the original work is properly cited.
로 평가되고 있다. 주요약용식물의 하나인 시호(Buplerum falcatum)는 미나리과(Umbelliferae)에 속하는 다년생 초본으로서 세계적으로 120 여종, 국내에서 5종 이상이 자생 재배되고 있으 며 뿌리를 생약재로 이용하는 약용식물 중의 하나이다(Jeong 등, 1998). 시호의 약리 부위는 뿌리이며 소염, 해열, 면역보강, 진 통, 궤양 치료 등 다양한 효과가 밝혀져 왔으며(Kimata 등, 1982; Yamada 등, 1991a; Matsumoto 등, 1993; Guo 등, 2000), 대표적인 항염증 약물로 분류되고 있다. 시호의 뿌리에는 지방 산으로 stearic acid, oleic acid, linolenic acid, palmitic acidem 이 함유되어 있고(Yamada 등, 1991b; Jeong 등, 1998), 시호의 주 약리 성분인 olenane계 saponin인 saikosaponin $\mathrm{a}$ 와 $\mathrm{d}$ 에 의 한 것으로 항염증, 상처치유 등 많은 연구에 의해 입증되고 있 으며(Kimata 등, 1982; Kim 등, 2011; Kim 등, 2012), saikosaponin c의 경우에도 당을 제거한 sapogenin이 동일한 약 리작용을 보이는 것으로 밝혀져 있다(Yamamoto 등, 1975). 피 부 노화(skin aging)는 피부 진피층에 존재하는 세포외기질 (extracellular matrix)의 구조적인 변화로 발생되는데(Makrantonaki 와 Zouboulis, 2007; Imokawa 등, 2008; Kim 등, 2008b; Tsuji-Naito 등, 2010) 구성요소 중 탄력섬유(elastic fiber)의 변 성과 교원질(collagen) 양의 감소가 피부의 주름을 야기한다 $(\mathrm{Kim}$ 등, 2010). 또한, 피부의 노화를 이끄는 주요 요인 중에는 collagen의 감소와 관련하여 자외선이나 스트레스에 의한 활성 산소의 생성을 들 수 있다. 피부에서의 활성 산소의 생성은 세 포막을 공격함으로써 세포에 손상을 입혀 그 기능을 상실하게 한다(Kim 등, 2006; Yeom 등, 2010). 피부세포로써의 기능상실 은 피부의 거친 상태를 형성하거나 유지시키고, 윤기를 없애는 결과를 초래함으로써 피부의 주름을 유발하게 된다 $(\mathrm{Kim}$ 등, 2006). 결국, 생체 내 활성산소의 생성은 matrix metalloprotease (MMPs) 유전자와 collagen 분해효소의 연쇄적인 활성화를 유도 함으로써 collagen의 구조적인 파괴를 유발하고, 피부의 탄력을 감소시키는 피부주름의 형성을 이끌게 된다(Park 등, 2010). 따 라서 피부노화는 collagen 분해효소와 활성산소의 생성억제, 
collagen의 합성을 촉진시킴으로써 피부노화의 완화 효과를 나 타낼 수 있다.

이에 본 연구는, 피부 섬유아세포를 이용하여 시호 추출물이 피부에 미치는 항노화 효과에 관한 연구를 수행하였으며, 피부 노화의 직접적인 원인인 matrix metalloprotease-1 (MMP-1)의 유전자 발현과 피부의 주요 구성인자인 콜라겐의 생합성 촉진 효과에 대해 검증하였다.

\section{재료 및 방법}

식물재료. 본 실험에 사용한 시호(Bupleurum falcatum)는 2009 년 2월 초순에 건조된 시호의 뿌리를 (주)HB (Human herb, Korea)에서 구입하여 깨끗이 세척한 뒤 실험재료로 사용하였다. 시약. 항산화능 측정 실험과 주름억제 효과 측정에 사용된 시 약인 1-1-diphenyl-2-picryl-hydrazyl (DPPH), porcine pancreas elastase, $N$-succinyl-(L-Ala) $)_{3}-p$-nitroanilide, collagenase 및 4phenylazobenzyloxycarbonyl-Pro-Leu-Gly-Pro-D-Arg 등은 Sigma Chemical Co. (USA)에서 구입하여 사용하였으며, 콜라겐 생합 성 측정에 사용된 시약은 procollagen type I C-peptide EIA kit (Takara-Bio Inc., Japan)을 구입하여 사용하였다.

시료 추출. 건조 된 시료 $100 \mathrm{~g}$ 을 분쇄하여 $1 \mathrm{~L}$ 의 $70 \%$ 에탄올 에 침지하여 24 시간 실온에서 방치한 후 상등액을 취한 다음 잔사에 이 방법을 반복하여 상등액을 취하였다. 앞서 얻은 상 등액과 합하여 얻은 여액을 다시 여지로 통과시켜 그 여액을 진공 증류기로 감압 농축한 다음 냉동건조하여 무게를 평량하 였으며 수율은 $13.8 \%$ 이었다. 본 실험에 사용된 시호 추출물은 Dimethyl sulfoxide (DMSO) 용매에 녹여진 $100 \mathrm{mg} / \mathrm{mL}$ 의 stock을 이용하여 사용하였으며, 증류수로 희석하여 사용하였다. 대조군은 시호 추출물 대신 희석용매인 증류수를 이용하여 본 실험에서 사용하였다.

DPPH 전자공여능 활성 측정. 전자공여능(electron donating ability)은 기존에 보고된 방법(Blois, 1958)을 변형하여 96 well plate에 맞게 수정하여 측정하였다. 각 시료용액 $2 \mathrm{~mL}$ 에 0.2 $\mathrm{mM}$ 의 DPPH $1 \mathrm{~mL}$ 넣고 교반한 후 30 분간 방치한 다음 517 $\mathrm{nm}$ 에서 흡광도를 측정하였다. 전자공여능은 시료용액의 첨가군 과 무첨가군의 흡광도 감소율로 나타내었다.

Elastase 저해활성 측정. 시호 추출물의 주름 효소 활성 저해능 을 평가하기 위해 elastase 활성을 측정하였다. 기질로서 $\mathrm{N}$ succinyl-(L-Ala) $)_{3}-p$-nitroanilide를 사용하여 $37^{\circ} \mathrm{C}$ 에서 20 분간 기 질로부터 생성되는 $p$-nitroanilide의 생성량을 $445 \mathrm{~nm}$ 에서 측정 하였다. 즉, 각 시험용액을 일정 농도가 되도록 조제하여 0.5 $\mathrm{mL}$ 씩 시험관에 취하고, $50 \mathrm{mM}$ tris- $\mathrm{HCl}$ buffer $(\mathrm{pH}$ 8.6)에 녹 인 porcine pancreas elastase $(2.5 \mathrm{U} / \mathrm{mL})$ 용액 $0.5 \mathrm{~mL}$ 을 가한 후 기질로 $50 \mathrm{mM}$ tris- $\mathrm{HCl}$ buffer $(\mathrm{pH} 8.6)$ 에 녹인 N-succinyl(L-Ala) $)_{3}-p$-nitroanilide $(0.5 \mathrm{mg} / \mathrm{mL})$ 을 첨가하여 20 분간 반응시 켜 측정하였다. Elastase 저해활성은 시료용액의 첨가구와 무첨 가구의 흡광도 감소율로 나타내었다.

세포독성 측정 및 세포주 배양. 세포 독성에 측정에 사용된 섬 유아세포 CCD-986sk 세포는 ATCC에서 구입하여 사용하였다. 세포 독성 측정 및 배양을 위해 dulbecco's modified eagle medium (DMEM), fetal bovine serum (FBS), penicillin/streptomycin, $0.4 \%$ trypan blue stain은 Gibco BRL Co. (USA)에서 구입하 였으며, haemacytometer (Germany), 3-[4,5-dimethylthiazol]-2- yl]-2,5-diphenyl-tetrazoliumbromide (MTT)는 Sigma Chemical Co. (USA)에서 구입하여 사용하였다. MMP-1 primary antibody 와 secondary antibody는 Santacruz (USA)에서 구입하였다. 본 실험에 이용한 각 세포의 배양은 $10 \% \mathrm{FBS}$ 과 $1 \%$ penicillin/ streptomycin $(100 \mathrm{U} / \mathrm{mL})$ 을 첨가한 DMEM 배지를 사용하였으 며, $37^{\circ} \mathrm{C}, 5 \% \mathrm{CO}_{2}$ incubator에 적응시켜 계대 배양하였다.

MTT assay에 의한 세포 독성 측정. CCD-986sk를 96 well plate에 $5 \times 10^{4}$ cells/well이 되게 $0.18 \mathrm{~mL}$ 분주하고, 시료를 농도 별로 조제하여 $0.02 \mathrm{~mL}$ 첨가한 후 $37^{\circ} \mathrm{C}, 5 \% \mathrm{CO}_{2}$ incubator에 서 48 시간 배양하였다. 여기에 $5 \mathrm{mg} / \mathrm{mL}$ 농도로 제조한 $\mathrm{MTT}$ 용액 $0.02 \mathrm{~mL}$ 를 첨가하여 4시간 배양한 후 배양액을 제거하고 각 well당 DMSO $0.15 \mathrm{~mL}$ 를 가하여 실온에서 30 분간 반응 시 킨 뒤 ELISA reader로 $540 \mathrm{~nm}$ 에서 흡광도를 측정하였다. 세포 독성 측정은 시료용액의 첨가군와 무첨가군의 흡광도 감소율로 나타내었다.

Pro-collagen 생합성 측정. CCD-986sk세포에 시호를 농도별로 처리했을 때 pro-collagen type I의 합성양을 측정하기 위해 96well plate에 각 well당 $1 \times 10^{4}$ cells/well 세포가 되도록 심어준 후 24시간을 안정화 하였다. 이후, 배양된 배지를 제거하고 시 호 추출물을 농도별로 처리한 후 48시간을 배양하였다. 각 well 로부터 상등액을 회수하여 procollagen Type-I C-Peptide EIA kit (Takara-Bio Inc.)의 각 well에 첨가한 후, 제조사의 방법에 따라 procollagen type I의 총 양을 측정 하였다.

Western blot을 이용한 단백질의 발현 측정. MMP-1 활성을 보 기 위하여 CCD-986sk세포를 $100 \mathrm{~mm}$ tissue culture dish에 cell seeding 후 24시간 동안 배양하여 cell을 안정화 시켰다. 배 지를 제거한 후 Phosphate buffered saline (PBS)로 교체하여 UV-B $\left(20 \mathrm{~mJ} / \mathrm{cm}^{2}\right)$ 를 60 초간 조사하였다. 그 후 추출물을 농도 별로 처리한 배지로 48시간 배양한 후 다시 배지를 제거하고 PBS로 2번 세척해주었다. Lysis buffer를 이용하여 CCD-986sk 세포를 분해하였다. 원심 분리하여 얻은 상층액은 정량하여 20 $\mu \mathrm{L}$ 의 단백질을 $10 \%$ 의 Sodium dodecyl sulfate polyacrylamide gel electrophoresis gel에서 전기 영동하여 분리하였다. 분리된 단백질은 PVDF membrane에 옮긴 다음 실온에서 1시간 blocking buffer (5\% skim milk in TBST)에서 incubation 시 켰다. MMP-1 각각의 1 차 항체를 $1: 1000$ 으로 희석하여 $4^{\circ} \mathrm{C}$ 에 서 over night한 다음, 다시 10 분 간격으로 $\mathrm{TBST}$ 로 3 회 washing하고 mouse anti-rabbit IgG HRP의 각각의 2차 항체를 $1: 1,000$ 로 희석하여 실온에서 2시간 동안 배양하였다. 3회 washing한 뒤 LAS 4,000 image analyzer (Fugifilm life science, Japan) 기기를 이용하여 밴드 확인 및 정량 하였다.

통계처리. 결과 통계처리는 SPSS 12.0 을 사용하였으며, 유의차 검증은 분산분석(ANOVA: analysis of variance) 프로그램을 이 용하여 t-test를 이용하여 통계적 유의수준 $p<0.05,0.01$ 에서 검 증하였다.

결 과

DPPH법을 이용한 free radical 소거 활성. 활성 산소는 피부 항산화제 파괴, 지질 과산화반응의 개시, 단백질의 산화, DNA 산화, 결합조직 성분인 콜라겐, 히아루론산 등의 사슬 절단 및 비정상적인 교차결합에 의한 주름생성, 멜라닌 생성과정에 참여 하는 등 피부노화를 가속시킨다(Park, 1997; Park 등 2003). 생 


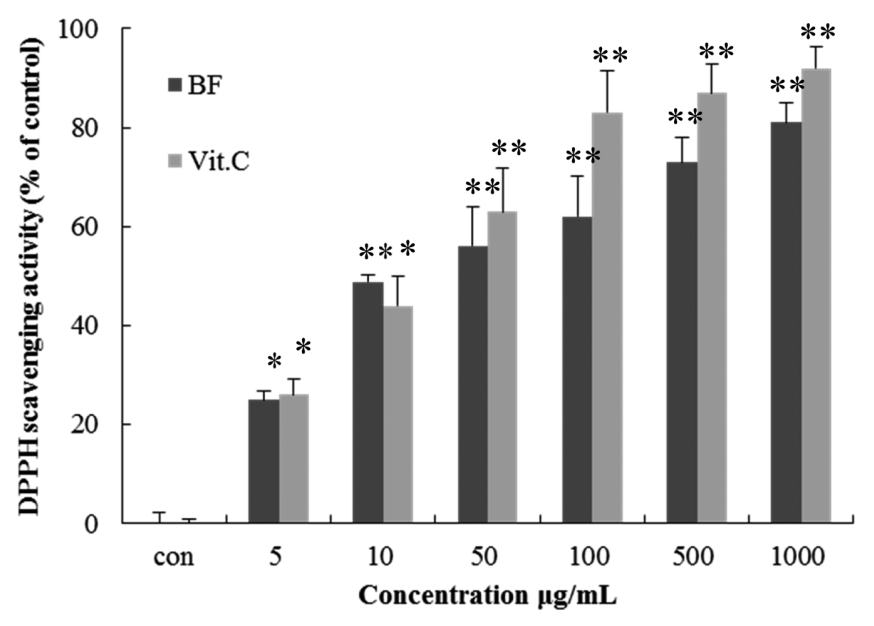

Fig. 1 Antioxidative effect of Buplerum falcatum. The values shown represent mean $\pm \mathrm{SEM}$ of three different assays. ${ }^{*} p<0.05,{ }^{*} p<0.01$ compared with absence of BF. BF: Buplerum falcatum Vit. C: Vitamin C

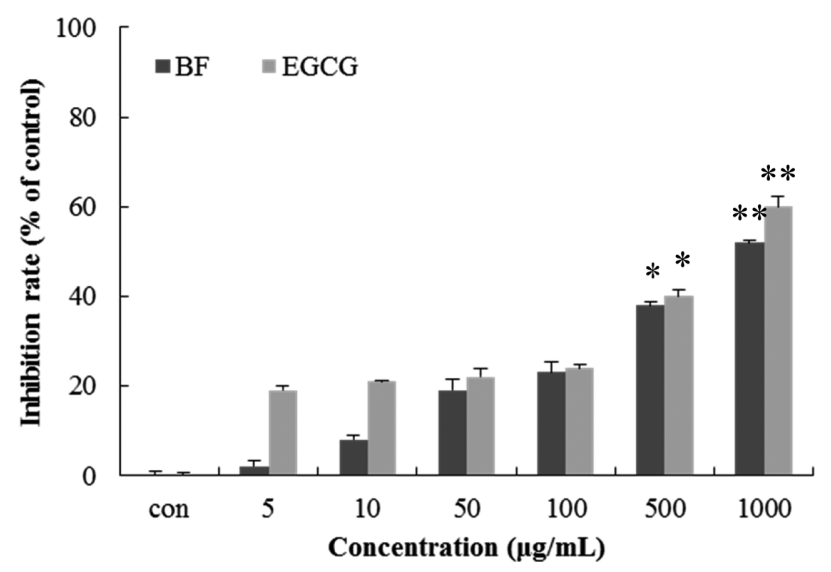

Fig. 2 Effect of Buplerum falcatum on inhibition of elastase. The values shown represent mean \pm SEM of three different assays. $* p<0.05$, ${ }^{* *} p<0.01$ compared with absence of BF. BF: Buplerum falcatum EGCG: Epigallocatechin gallate

체막에 있어 활성 산소 또는 지질 라디칼에 의해 개시된 지질 과산화 반응은 자동산화 과정을 경유한 연쇄반응이다. Vitamin $\mathrm{C}$ (vit. C) 등의 항산화제는 연쇄반응에서 지질 과산화라디칼에 수소 주개로 작용하여 연쇄 반응을 종결시킨다. 이때 수소 주 개로 작용하는 항산화제의 능력은 안정한 free radical 인 $\mathrm{DPPH}$ 와의 반응을 통하여 알아 볼 수 있다. 시호 추출물에 대 한 free radical 소거 활성 측정 결과 $1,000 \mu \mathrm{g} / \mathrm{mL}$ 의 농도에서 $80 \%$ 저해 활성을 가지는 것을 확인하였으며, free radical을 $50 \%$ 로 저해 할 수 있는 농도 $\left(\mathrm{IC}_{50}\right)$ 가 $29.3 \mu \mathrm{g} / \mathrm{mL}$ 의 농도임을 확인하였다. 또한 vit. C는 $1,000 \mu \mathrm{g} / \mathrm{mL}$ 의 농도에서 $91 \%$ 저해 활성능과 $\mathrm{IC}_{50}$ 이 $28.6 \mu \mathrm{g} / \mathrm{mL}$ 농도 일 경우와 비교 시 유사한 소 거 활성을 가진 것으로 확인되었다(Fig. 1).

Elastase 활성 저해효과. 피부노화 현상은 피부세포 내 생체결 합수의 손실, 피부 각질층의 구조변화, 표피세포의 분화감소, 진 피내 섬유아세포에 의한 단백질 및 세포간 물질의 생체 합성기 능 저하등에 의해 나타난다(Wiedow 등, 1990). 많은 연구에서 나이와 주름이 피부 탄력과 상호연관성이 있음을 보고하였으며,

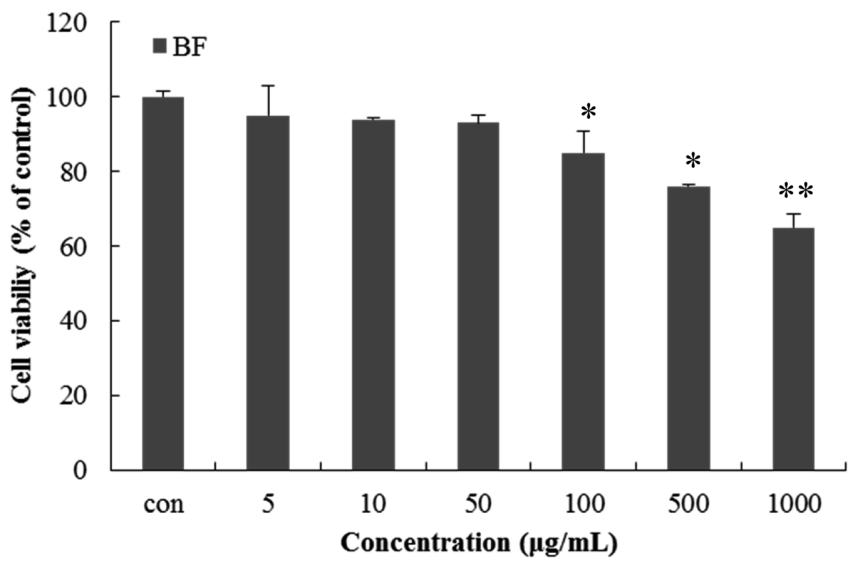

Fig. 3 Effect of Buplerum falcatum on proliferation of CCD-986sk. CCD-986sk cells were incubated for $24 \mathrm{~h}$ in DMEM medium containing $10 \%$ FBS, were treated with various concentrations of $\mathrm{BF}$ for $48 \mathrm{~h}$ and cell viability was measured by MTT reagent. The values shown represent mean \pm SEM of three different assays. ${ }^{*} p<0.05,{ }^{* *} p<0.01$ compared with absence of BF. BF: Buplerum falcatum

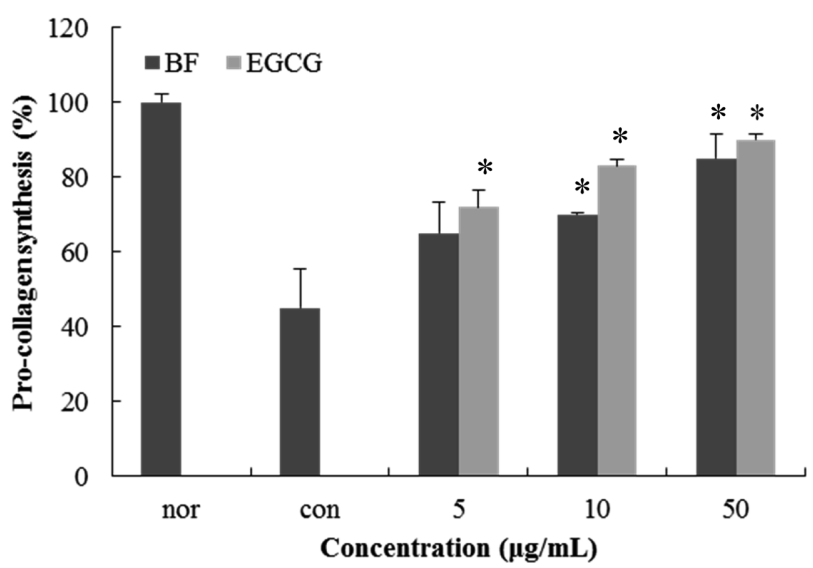

Fig. 4 Effect of Buplerum falcatum on pro-collagen type I synthesis. CCD-986sk cells were incubated for $24 \mathrm{~h}$ in DMEM medium containing $10 \%$ FBS, were treated with various concentrations of BF for $48 \mathrm{~h}$. The supernatant was collected from each well and type I procollagen was determined by EIA kit. The values shown represent mean \pm SEM of three different assays. ${ }^{*} p<0.05$ compared with absence of BF. BF: Buplerum falcatum EGCG: Epigallocatechin gallate, nor: normal (not UVB), con: control (UVB, not treated Buplerum falcatum)

elastin은 주름의 형성과 밀접하게 연관되어 있으며 피부 탄력의 감소는 주름을 형성하게 된다(Imokawa 등, 1995). 피부의 진피 조직 속에는 collagen과 피부의 탄력성에 관련된 elastin이 그물 망 구조를 형성하고 있는데, 이러한 그물망 구조가 깨어지면서 즉, elastin이 elastase에 의해 분해되어 피부가 처지고 주름이 생 기므로 내인성 피부노화가 발생한다(Lee 등, 2003a). 그러므로 피부 노화의 주원인 중의 하나인 elastin 분해 효소인 elastase의 활성을 저하시킴으로써 피부노화를 억제할 수 있다. 이처럼 elastin을 가수분해하는 elastase는 피부 주름과 연관성이 있는 효 소로서 시호 추출물이 elastase 활성에 미치는 영향을 관찰하였 다. 시호 추출물에서 농도 의존적으로 효소활성을 억제하였으며, 최고 농도 $1,000 \mu \mathrm{g} / \mathrm{mL}$ 에서 $52 \%$ 로 효소 활성을 억제하였으며, 

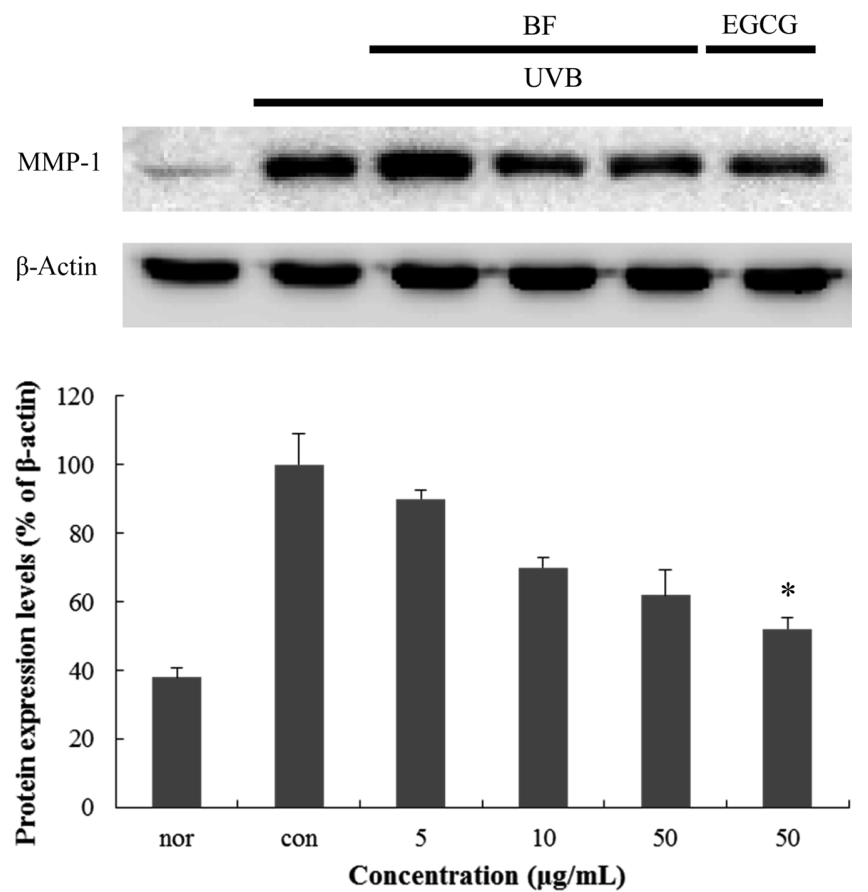

Fig. 5 Effect of Buplerum falcatum on MMP-1 gene expression. CCD986sk cells were incubated for $24 \mathrm{~h}$ in DMEM medium containing $10 \%$ FBS, were treated with various concentrations of BF for $48 \mathrm{~h}$ and then total protein was isolated. MMP-1 protein level was determined by western blot. The values shown represent mean \pm SEM of three different assays. ${ }^{*} p<0.05,{ }^{* *} p<0.01$ compared with absence of $\mathrm{BF}$. nor: normal (not UVB, not treated Buplerum falcatum), con: control (UVB, not treated Buplerum falcatum)

$\mathrm{IC}_{50}$ 농도가 $915.4 \mu \mathrm{g} / \mathrm{mL}$ 임을 확인 할 수 있었다. 주름 관련 효 소를 억제에 뛰어난 효능을 가지는 Epigallocatechin gallate (EGCG)와 비교시 같은 농도에서 elastase 효소 억제능은 $60 \%$ 였으며 $\mathrm{IC}_{50} 750 \mu \mathrm{g} / \mathrm{mL}$ 임을 나타내어 시호 추출물이 같은 농도 에서 $\mathrm{EGCG}$ 와 비슷한 활성을 가지는 것을 확인 할 수 있었다 (Fig. 2). 이와 같은 결과로 보아 시호 추출물은 피부탄력 저하 활성 효능을 지니기에 기능성 소재로서의 가능성을 시사하여 준다. Fibroblast cell (CCD-986sk)의 생존율 확인. 시호 추출물의 CCD-986sk에 미치는 영향 및 세포독성과 더불어 시험에 사용 될 농도 범위 결정을 위해서 MTT assay를 시행하였다. 시호 추출물을 농도별 $(5,10,50,100,500,1,000 \mu \mathrm{g} / \mathrm{mL})$ 로 처리한 결과 $5,10,50 \mu \mathrm{g} / \mathrm{mL}$ 처리 시 섬유아세포 생존율에 큰 영향을 나타내지 않았지만, $100,500,1,000 \mu \mathrm{g} / \mathrm{mL}$ 의 농도 별 처리 시 에는 세포의 생존율이 $85,76,65 \%$ 로 감소되는 것을 확인 할 수 있었다(Fig. 3). 따라서 본 연구에서 CCD-986sk 세포 내 시 호 추출물의 pro-collagen 합성 촉진 효과 측정 및 $\mathrm{MMP}-1$ 발 현 측정을 확인하기 위해서 세포 생존율이 $100 \%$ 가까운 농도 인 $5,10,50 \mu \mathrm{g} / \mathrm{mL}$ 을 사용하였다.

Pro-collagen 합성 촉진 효과 측정. 세포외기질의 주요 구성 성 분인 collagen은 피부의 섬유아세포에서 생성되는 주요 기질 단 백질로 피부의 기계적 견고성, 결합 조직의 저항력과 조직의 결 합력, 세포 접착의 지탱, 세포 분할과 분화의 유도 등의 기능을 가지고 있다. 콜라겐(type I, II, III, IV, and V)들은 프로 콜라 겐이라는 전구물질의 형태로 합성된다. Pro-collagen은 아미노
말단과 카복시 말단에 프로펩티드라는 펩티드 염기서열을 포함 하며, 콜라겐 중합 반응이 일어날 때 콜라겐 분자로부터 절단, 분리되는 기능을 가진 것으로 알려져 있다. 따라서 프로펩타이 드의 양을 측정함으로써, 세포내에서의 콜라겐 생합성 정도를 파악할 수 있다(Parfitt 등, 1987; Kim 등, 2008b). 콜라겐은 피 부의 주름 형성과 밀접한 연관이 있으며 콜라겐이 부족할 경우 주름이 유발될 수 있다. 따라서 콜라겐의 합성을 촉진시킬 수 있는 소재는 탄력 있는 피부를 만들어주는 화장품 원료로서 사 용 가능하다고 생각 하여 시호 추출물로 collagen 합성 실험을 하였다. 섬유아세포에 $\mathrm{UVB}$ 를 조사한 결과 정상군에 비해 procollagen 생합성율이 $50 \%$ 이상 저해 되었으며, 시호 추출물을 처리하여 pro-collagen의 생합성의 활성효능을 확인하였다. 그 결과, 시호 추출물은 각각 $5,10,50 \mu \mathrm{g} / \mathrm{mL}$ 의 농도에서 65,70 , $80 \%$ 로 pro-collagen 생합성을 나타내었으며 대조물질인 EGCG 와 비슷한 효능을 나타내었다. 이와 같이 시호 추출물은 피부 세포중 하나인 CCD-986sk에서의 pro-collagen 생합성 율도 농 도 의존적으로 유의성 있게 촉진 시키는 것을 확인 할 수 있었 다(Fig. 4).

MMP-1 유전자 발현의 억제. 피부세포의 결합조직을 구성하는 성분 중 collagen은 약 $90 \%$ 정도를 차지하는 중요한 구성 단백 질이다. Collagen은 trypsin 등의 단백질 분해효소에는 영향을 받지는 않지만, collagenase의 영향에 의해 분해된다(Kim 등, 2008b; Lee 등, 2003b). Collagen을 분해하는 주요 효소중에는 전사인자인 active protein-1에 의해 유도되는 MMP-1에 의해 일어나는 것이 일반적이다(Kim 등, 2006; Kim 등, 2008a). MMP-1은 type collagen을 분해함으로써 collagen의 합성을 억 제하는 분해인자로 알려져 있다(Kim 등, 2004; Suganuma 등, 2010). 그러므로, MMP-1활성의 억제는 곧 collagen 분해를 감 소시켜 피부 탄력의 유지 및 주름 형성을 억제 할 수 있으리라 판단되어 protein level에서의 MMP-1 유전자의 발현 변화를 측 정하였다. 그 결과, 섬유아세포에 처리된 시호 추출물의 농도가 증가 할수록 비처리군에 비해 MMP-1의 유전자 발현이 농도 의존적으로 억제되는 것을 확인할 수 있었다(Fig. 5). 시호 추 출물은 collagen의 직접적인 분해효소인 MMP-1의 발현을 protein level에서 억제함으로써, 피부 주름의 형성을 억제하는 것으로 판단되고, 이는 주박을 이용한 피부주름개선 화장품의 개발의 가능성을 제시한다.

\section{초 록}

시호 추출물로부터 자외선에 의한 주름개선 효과를 확인하여 화 장품 소재로서의 가능성을 검증하였다. 주름 활성 검증을 위하여 전자공여능, elastase, pro-collagen 생합성, Matrix metalloprotease1 (MMP-1)의 활성을 측정하였다. 시호 추출물의 세포 독성을 측정하기 위하여 MTT assay를 하여 세포 독성이 $100 \%$ 에 가 까운 농도인 $5,10,50 \mu \mathrm{g} / \mathrm{mL}$ 의 농도에서 pro-collagen 생합성 과 $\mathrm{MMP}-1$ 의 활성 검증하였다. 시호 추출물의 전자 공여능과 elastase 활성을 측정한 결과 $1,000 \mu \mathrm{g} / \mathrm{mL}$ 의 농도에서 각각 80 , $52 \%$ 의 저해 활성을 가졌다. 또한 pro-collagen 생합성 역시 $\mathrm{UVB}$ 를 조사한 후 시호 추출물을 농도 별로 처리 한결과 농도 의존적으로 증가하는 것을 확인하였다. 주름생성에 관련되어져 있는 MMP-1의 발현을 알아본 결과 시호 추출물에 의해 total protein 양이 또한 감소되는 것을 확인 할 수 있었다. 따라서 시 
호는 주름활성을 개선시킬 수 있는 기능성 소재로 활용 될 수 있을것으로 사료된다.

\author{
Keywords 기질금속단백질분해효소-1 - 시호 · 주름 · 프로콜 \\ 라겐
}

\section{Rererences}

Blois MS (1958) Antioxidant determination by the use of a stable free radical. Nature 181, 1199-20.

Guo Y, Mastsumoto T, Kikuchi Y, Ikejima T, Wang B, and Yamada H (2000) Effect of apectic polysaccharide from a medicinal herb, the roots of Bupleurum falcatum L. on interleukin 6 production of murine B cells and B cell lines. Immunopharmaco 49, 307-16.

Imokawa G (2008) Recent advances in characterizing biological mechanisms underlying UV-induced wrinkles: a pivotal role of fibrobrast-derived elastase. Arch Dermatol Res 300, 7-20.

Imokawa G, Takema Y, Yorimoto Y, Tsukahara K, Kawai M, and Imayama S (1995) Degree of ultraviolet-induced tortuosity of elastic fibers in rat skin is age dependent. J Invest dermatol 105, 254-8.

Jeong HJ, Kim KU, Lee SC, Kim GW, and Chung GY (1998) Comparion on morphology and saikosaponin centents of Bupleurum falcatum produced in korea and china. Korean J Plant Res 11, 283-9.

Kim EJ, Kim MK, Jin XJ, Oh JH, Kim JE, and Chung JH (2010) Skin aging and photoaging alter fatty acids composition, including 11,14,17eicosatrienoic acid, in the epidermis of human skin. J Korean Med Sci 25, 980-3.

Kim HH, Cho S, Lee S, Kim KH, Cho KH, Eun HC et al. (2006) Photoprotective and anti-skin-aging effects of eicosapentaenoic acid in human skin in vivo. J Lipid Res 47, 921-30.

Kim LD, Kwon RH, Heo YY, Jung HJ, Kang YY, and Bae JH (2008a) Supercritical extraction of oriental herb: anti-aging and anti-wrinkle effects. Korean J Biotechnol Bioeng 23, 259-534.

Kim MJ, Kim JY, Jung TK, Choi SW, and Yoon KS (2006) Skin anti-aging effect of Forsythia viridissima L. extract. Korean J Biotechnol Bioeng 21, 444-50.

Kim SH, Yong HJ, Shin C, and Ko SG (2008b) Research of traditional herba medicines for anti-aging, inhibition effect of wrinkle and whitening effect in the skin. Korean J Ori Physiol Pathol 22,691-8.

Kim SM, Ku SK, Cho SY, and Park SJ (2012) Effect of Bupleuri radix on the rat hypothyroidism induced by PTU(6-n-propyl-2-thourail). Korean J Ori Physiol Pathol 22, 714-23.

Kim SY, Kim SJ, Lee JY, Kim WG, Park WS, Sim YC et al. (2004) Protective effects of dietary soy isoflavones against UV-induced skin-aging in hairless mouse model. J Am Coll Nutr 23, 157-62.

Kim YS, Cho IH, jeong MJ, Jeong SJ, Nah SY, Cho YS et al. (2011) Therapeutic effect of total ginseng saponin on skin wound healing. $J$
Ginseng Res 35, 360-7.

Kimata M, Kasai R, and Tanaka O (1982) Saponins of juk-siho and roots of Bupleurum longenadiatum Turcz. Chem Pharm Bull 30, 4373-7.

Lee SY, An JH, and Cho HY (2003a) Isolation and characterization of MMP1 inhibitor peptide from Crataegus pinnatifida bunge in fibroblast cell line HS68 cells. J Kor Soc Argic Chem Biogechno 46, 60-5.

Lee YS, Jin DQ, Beak SM, Lee ES, and Kim JA (2003b) Inhibition of ultraviolet-A-modulated signaling pathways by asiatic acid and ursolic acid in HaCaT human keratinocytes. Eur J Pharmacol 476, 173-8.

Makrantonaki E and Zouboulis CC (2007) Molecular mechanisms of skin aging: state of the art. Ann NY Acad Sci 1119, 40-50.

Matsumoto T, Cyong JC, Kiyohara H, Matsui H, Abe A, Hirano $\mathrm{M}$ et al. (1993) The pectic polysaccharide from Bupleurum falcatum L. enhances immune complexes binding to peritoneal macrophages through fo receptor expression. Inter J Immunopharmacol 15, 683-93.

Parfitt AM, Simon LS, Villanueva AR, and Krane SM (1987) Procollagen type carboxy-terminal extension peptide in serum as a marker of collagen biosynthesis in bone Correlation with iliac bone formation rates and comparison with total alkaline phosphatase. J Bone Miner Res 2,427-36.

Park HJ, Ock SM, Kim HJ, Park HJ, Lee YB, Choi JM et al. (2010) Vitamin $\mathrm{C}$ attenuates ERK signaling to inbihit regulation of collagen production by LL-37 in human dermal fibroblasts. Exp Dermatol 19, 258-64.

Park SN (1997) Skin aging and antioxidant . J Soc Cosmet Scientists kor 23, 75.

Park SN (2003) Antioxidative properties of baicalein, components from scutellaria baicalensis georgi and its application to cosmetics (I). $J$ Korean Ind Eng Chem 14, 657.

Suganuma K, Nakajima H, Ohtsuki M, and Imokawa G (2010) Astaxanthin attenuates the UVA-induced up-regulation of matrix-metalloproteinase-1 and skin fibroblast elastase in human dermal fibroblasts. J Dermatol Sci 58, 136-42.

Tsuji-Naito K, Ishikura S, Akagawa M, and Saeki H (2010) Alpha-Lipoic acid induces collagen biosynthesis involving prolyl hydroxylase expression via activation of TGF-beta-Smad signaling in human dermal fibroblasts. Connect Tissue Res 51, 378-87.

Wiedow OJ, Schroder M, and Christophers E (1990) Elafin: an elastase specific inhibition of human skin. J Biol Chem 265, 14791-801.

Yamada H, Hirano M, and Jiyohara H (1991a) Partial structure of an antiulcer pectic polysaccharides from roots of Bupleurum falcatum. Carbohyd Res 219, 173-92.

Yamada H, Sun XB, Matsumoto T, Ra KS, Hirano N, and Kiyohara H (1991b) Purification of anti-ulcer polysaccharides from the roots of Bupleurum falcatum. Plant medicine 57, 555-9.

Yamamoto M, Kumagai A, and Yamamura Y (1975) Structure and action of saikosaponins isolated from Bupleurum falcatum L. I. Antiinflammatory actions of saikosaponin. Arzrin Forsch. Drug Res 25, 1021-3.

Yeom MH, Lee JY, Kim JS, Park CW, Kim DH, and Kim HK (2010) The anti-aging effects of Korean Ginseng Berry in the skin. Korean $J$ Pharmacogn 41, 26-30. 